\title{
MJN SKILLS IN EARLY WARNING SCORE SHEET FILLING WITH NURSING DECISION MAKING IN CODE BLUE TEAM ACTIVATION
}

\author{
Ekwantoro*, Kuswantoro Rusca Putra, Setyoadi \\ Brawijaya University, Malang, Indonesia \\ *Corresponding Author's Email: exwanagata35@gmail.com
}

\begin{abstract}
Background: Code blue team activation decision making always begins with recommendations from the Early Warning Score (EWS) sheet. Adequate skills in filling EWS sheets have an impact on the nurse's ability to make decisions for activation of the code blue team. This study aims to determine the relationship between the skills in filling EWS sheets with nurse decision making in code blue activation in the hospital. Methods: The study design was observational analytic with the cross-sectional approach. The sampling technique used was simple random sampling consisting of 93 nurses. Nurses' skills were measured by the method of observation and decision making using "The Nurse Decision Making Instrument questionnaire". Results: The results show that nurses' skills in filling EWS sheets 58\% were categorized skillful. The majority of nurse decision making was $72 \%$ intuition. Statistical test results show a significant relationship between skills and decision-making activation code blue team $(r=0.207, p=0.013)$ Conclusion: The increase was found in skills in filling the EWS sheets required and the decisions were made on the recommendations of the EWS.
\end{abstract}

Keyword: Skills, Early Warning Score, Decision Making, Code Blue

\section{INTRODUCTION}

Early warning score (EWS) is used to monitor the patient's vital signs and to detect early or absent emergencies of patients in hospitalization (Lydon et al., 2016). Patients with cardiac arrest and death are often marked by abnormal changes in vital signs several hours earlier (Mathukia et al., 2015). Changes in vital signs can be known through monitoring conducted by nurses, so there is no sudden emergency (Gardner-Thorpe et al., 2006). EWS can also be used as a basis for activating the code blue team in the hospital.

So far, the application of EWS has not been optimal. Lapkin et al., (2010) stated that there were skill factors to detect the clinical condition of patients. Damayanti, Trisyani \& Nuraeni, (2019) stated that nurses' skills in calculating and understanding EWS are still not optimal. Skills in EWS filling and early detection of patient deterioration are needed by nurse (McGaughey et al., 2017). The skills to identify patients at risk are very important for determining subsequent decision making (Bick et al., 2014). One of the nurses' skills during clinical emergencies in patients is activating the code blue team based on recommendations from the EWS (Jansen \& Cuthbertson, 2010).

Some code blue team countries are combined with the Rapid Response Team related to human resources (Odell, Victor \& Oliver, 2009; Rashid et al., 2014). The application of code blue team activation can affect the quality of service and improve the quality of life of patients in the Hospital (Jones et al., 2013). Improved services due to interventions carried out by the code blue team in critical patients were able to reduce the mortality rate by $17-23 \%$ (Konrad et al., 2010). The risk of death in critical patients in hospital services decreased by $12 \%$ after the activation of the code blue team (Konrad et al., 2010). Other research showed that with the activation of the code blue team there was $18-19 \%$ reduction of cases of death due to cardiac arrest in inpatient services (Sabahi et al., 2012; Sharek et al., 2007).

Therefore, this study discusses a relationship between skills in filling up the EWS sheets with decision making in the activation of the code blue team at the hospital. 


\section{METHODOLOGY}

\section{Study Design}

The research design was observational analytic with the cross-sectional approach, linking the skills with the decision making of code blue team activation. The study was conducted from March to May 2020.

\section{Subject}

Respondents in this study were 93 ward nurses in one hospital in East Java. Respondent criteria used were nurses who had worked for $\geq 1$ year and performed inpatient services.

\section{Measurement}

The skill observed in this research is completing EWS sheets while the nurse was serving in 1 day. The criterion for skills is "Skillful" if the nurses filled out the EWS score correctly and the recommendations needed in the EWS sheet. Meanwhile, "Not skilled" is given if the nurses were wrong in filling out EWS sheets.

The nurse decision-making questionnaire uses "The Nurse Decision Making Instrument" (Lauri \& Salanterä, 2002). The questionnaire consists of 24 questions graded from 1-5, using a Likert scale with choices, "always", "often" "sometimes" and "never", "never at all". Decision making categories include score $<67$ Analysis, score 68 78 Quasirational, and score $>79$ Intuition. This instrument has been tested for validity with the results of $r>0.46$ ( $r$ table), and reliability with Cronbach's alpha of 0.844 .

\section{RESULTS}

\section{Characteristics of Respondents}

The results showed that the average age of the respondents was 34.07 (between 24 - 48 years). Most of them are female $(61.3 \%)$, with diploma level education $(75.3 \%)$ and an average of 11 years of work experience (Table 1).

Table 1: Characteristics of Respondents $(\mathrm{n}=93)$

\begin{tabular}{|l|c|}
\hline Characteristics & Results \\
\hline $\begin{array}{l}\text { Age, years } \\
\text { (average } \pm \text { SD) }\end{array}$ & $34 \pm 6.97$ \\
\hline Experience, years (average \pm SD) & $11 \pm 7.37$ \\
\hline Sex & $36(38.7 \%)$ \\
Male & $57(61.3 \%)$ \\
Female & \\
\hline Education & $70(75.3 \%)$ \\
D3 Nurse & $23(24.7 \%)$ \\
S1 Nurse & \\
\hline
\end{tabular}

The results show that of the respondents who were skillful in filling the EWS sheets were 54 respondents (58\%), while the less skillful were 39 respondents $(42 \%)$. Decision making by majority respondents were intuitive decision making by 67 (72\%) (Table 2).

Table 2: Frequency Distribution of Skills and Decision Making

\begin{tabular}{|l|l|c|c|}
\hline Variable & Category & Frequency & Percentage \\
\hline \multirow{4}{*}{ Skill } & Skilled & 54 & $58 \%$ \\
\cline { 2 - 4 } & No Skilled & 39 & $42 \%$ \\
\cline { 2 - 4 } & Total & 93 & $100 \%$ \\
\hline \multirow{3}{*}{$\begin{array}{l}\text { Decision } \\
\text { making }\end{array}$} & Intuition & 67 & $72 \%$ \\
\cline { 2 - 4 } & Quasirational & 21 & $22 \%$ \\
\cline { 2 - 4 } & Analysis & 5 & $5.4 \%$ \\
\cline { 2 - 4 } & Total & 93 & $100 \%$ \\
\hline
\end{tabular}

The results of cross-tabulation between the skills and decision making showed that respondents who were in the skilled category in terms of filling out the EWS tended to choose intuitive decisions in the activation of the code blue team were shown by 34 respondents $(36.6 \%)$. The statistical test using Kendal Tau shows that there was a significant relationship between skills and nurse decision making in the activation of code blue team $(0.04<0.05)$ with a positive correlation value and has weak strength .

Table 3: Bivariate Analysis of The Relationship Between Skills and Decision Making

\begin{tabular}{|c|c|c|c|c|c|c|c|}
\hline & \multicolumn{4}{|c|}{ Skill } & \multirow{3}{*}{$\begin{array}{l}\text { correlation } \\
\text { coefficient }\end{array}$} & \multirow{3}{*}{$\begin{array}{c}\text { Value } \\
p\end{array}$} \\
\hline & & \multicolumn{2}{|c|}{ No Skille } & \multicolumn{2}{|c|}{ Skilled } & & \\
\hline & & $\mathrm{F}$ & $\%$ & $\mathrm{~F}$ & $\%$ & & \\
\hline \multirow{3}{*}{$\begin{array}{l}\text { Decision } \\
\text { making }\end{array}$} & Intuition & 33 & 35.5 & 34 & 36.6 & \multirow{4}{*}{0.207} & \multirow{4}{*}{0.043} \\
\hline & Quasirational & 3 & 3.2 & 18 & 19.4 & & \\
\hline & Analysis & 3 & 3.2 & 2 & 2.2 & & \\
\hline & Total & 39 & 41.9 & 54 & 58.1 & & \\
\hline
\end{tabular}

\section{DISCUSSION}

This study discusses nurses' skills in identifying signs of clinical deterioration of patients based on the Early Warning Score (EWS) of the patient. The results showed that most respondents were skillful in filling the Early Warning Score (EWS) sheet. These skills include temperature, pulse, respiration, oxygen saturation, blood pressure, and the patient's level of consciousness. The nurse's skill in filling out this EWS sheet was found that the recording of vital signs in the EWS was not accompanied by follow-up on what had been recommended by the EWS sheet. This shows that the problem in terms of skills in filling EWS is process that 
nurses maintain to follow up on changes in vital signs that occur in patients (Niegsch, Fabritius \& Anhøj, 2013).

Decision making in this study is the nurse's decision to activate the code blue team based on the decrease in the clinical condition of the patient on the EWS sheet. The results show that most of the respondents used intuitive decisions. This is in line with research by Mohammed et al., (2017) stating that decision making with intuition style is a decision making technique that is fast and is formed from skills gained from experience. Decision making in code blue team activation may be better and more accurate if there is a component of intuition and analysis in the nursing process (Simmons, 2010). The different reasoning strategies between intuition and analysis have an impact on the quality of decision making. In this case, the intuition formation and analysis are related to a nurse's knowledge in the development of the nursing process. The approach in the nursing process requires nurses to make judgments and decisions. This is the basis in forming intuition and analysis (MelinJohansson, Palmqvist \& Ronnberg, 2017).

The statistical test shows that there was a correlation between the skills to fill in the EWS sheets with the nurse's decision making in the activation of the code blue team. This is in line with Massey, Chaboyer \& Aitken, (2014) stating that skills in early detection of changes in patient conditions affect nurses' decisions in the activation of the code blue team at the hospital. Skills and competencies are created through the capacity of nurses to integrate the knowledge of abilities and experiences in decision making (Cowan, Norman \& Coopamah, 2015). Skills in assessing EWS have to do with experience and decision making of code blue team activation (Waldie, Tee \& Day, 2016). Nurses' skills and decision making are always followed by experience or years of service inhospital services. In this study, it is known that the average nurse experience was 11 years. Sesrianty (2018) stated that the longer the person work in a workplace, the more skillful and experienced and are more able to make decisions. The nurse's skills and experience can increase the use of intuitive decision making, even though intuitive decision making is no better or worse than analysis and another decision making (Pretz \& Folse, 2011).

\section{CONCLUSION}

The nurse's decision-making skill in the activation of the code blue team is always in line with the nurse's skill in detecting the clinical deterioration of the patient. The increase was found in skills in filling the EWS sheets required and the decisions were made on the recommendations of the EWS.

\section{Conflict of Interests}

The authors declare that they have no conflict of interest.

\section{ACKNOWLEDGEMENT}

The authors are thankful to the institutional authority for completion of the work.

\section{REFERENCES}

Bick, D. E., Sandall, J., Furuta, M., Wee, M. Y. K., Isaacs, R., Smith, G. B. \& Beake, S. (2014). A national crosssectional survey of heads of midwifery services of uptake, benefits and barriers to use of obstetric early warning systems (EWS) by midwives. Midwifery, 30(11), pp 1140-1146.

Cowan, D.T., Norman, I. \& Coopamah, V.P. (2015). Competence in nursing practice: a controversial concept--a focused review of literature. Nurse Education Today, 25(5), pp 355-362.

Damayanti, R., Trisyani, Y. \& Nuraeni, A. (2019). Effects of Early Warning Score (EWS) Tutorial Simulation on Nurses' Knowledge and Clinical Performance. Nurse Media Journal of Nursing, 9(2), pp 231-241.

Gardner-Thorpe, J., Love, N., Wrightson, J., Walsh, S. \& Keeling, N. (2006). The value of Modified Early Warning Score (MEWS) in surgical in-patients: a prospective observational study. Annals of the Royal College of Surgeons of England, 88(6), pp 571-575.

Jansen, J.O. \& Cuthbertson, B.H. (2010). Detecting critical illness outside the ICU: the role of track and trigger systems. Current Opinion in Critical Care, 16(3), pp 184-190.

Jones, D., Moran, J., Winters, B.\& Welch, J. (2013). The rapid response system and end-of-life care. Current Opinion in Critical Care, 19(6), pp 616-623.

Konrad, D., Jäderling, G., Bell, M., Granath, F., Ekbom, A. \& Martling, C. R. (2010). Reducing in-hospital cardiac 
arrests and hospital mortality by introducing a medical emergency team. Intensive Care Medicine, 36(1), pp $100-106$

Lapkin, S., Levett-Jones, T., Bellchambers, H. \& Fernandez, R. (2010). Effectiveness of Patient Simulation Manikins in Teaching Clinical Reasoning Skills to Undergraduate Nursing Students: A Systematic Review. Clinical Simulation in Nursing, 6(6), e207-e222.

Lauri, S. \& Salanterä, S. (2002). Developing an instrument to measure and describe clinical decision making in different nursing fields. Journal of Professional Nursing, 18(2), pp 93-100.

Lydon, S., Byrne, D., Offiah, G., Gleeson, L. \& O'Connor, P. (2016). A mixed-methods investigation of health professionals' perceptions of a physiological track and trigger system. BMJ Quality \& Safety, 25(9), pp 688-695.

Massey, D., Chaboyer, W. \& Aitken, L. (2014). Nurses' perceptions of accessing a Medical Emergency Team: A qualitative study. Australian Critical Care, 27(3), pp 133-138.

Mathukia, C., Fan, W., Vadyak, K., Biege, C. \& Krishnamurthy, M. (2015). Modified Early Warning System improves patient safety and clinical outcomes in an academic community hospital. Journal of Community Hospital Internal Medicine Perspectives, 5(2), 26716.

McGaughey, J., O’Halloran, P., Porter, S., Trinder, J. \& Blackwood, B. (2017). Early warning systems and rapid response to the deteriorating patient in hospital: A realist evaluation. Journal of Advanced Nursing, 73(12), pp 3119-3132.

Melin-Johansson, C., Palmqvist, R. \& Ronnberg, L. (2017). Clinical intuition in the nursing process and decisionmaking-A mixed-studies review. Journal of Clinical Nursing, 26(23-24), pp 3936-3949.

Mohammed, A., Elrehail, H., Alatailat, M.A. \& Elçi, A. (2017). Knowledge management, decision-making style and organizational performance. Journal of Innovation \& Knowledge, 4(2), pp 104-114.

Niegsch, M., Fabritius, M.L. \& Anhøj, J. (2013). Imperfect Implementation of an Early Warning Scoring System in a Danish Teaching Hospital: A Cross-Sectional Study. PLOS ONE, 8(7), e70068. Retrieved from: https://doi.org/10.1371/journal.pone.0070068

Odell, M., Victor, C. \& Oliver, D. (2009). Nurses' role in detecting deterioration in ward patients: Systematic literature review. Journal of Advanced Nursing, 65(10), pp 1992-2006.

Pretz, J.E. \& Folse, V.N. (2011). Nursing experience and preference for intuition in decision making. Journal of Clinical Nursing, 20(19-20), pp 2878-2889.

Rashid, M.F., Imran, M., Javeri, Y., Rajani, M., Samad, S. \& Singh, O. (2014). Evaluation of rapid response team implementation in medical emergencies: A gallant evidence-based medicine initiative in developing countries for serious adverse events. International Journal of Critical Illness and Injury Science, 4(1), pp 3-9.

Sabahi, M., Fanaei, S.A., Ziaee, S. A. \& Falsafi, F.S. (2012). Efficacy of a rapid response team on reducing the incidence and mortality of unexpected cardiac arrests. Trauma Monthly, 17(2), pp 270-274.

Sesrianty, V. (2018). Hubungan Pendidikan Dan Masa Kerja Dengan Keterampilan Perawat Melakukan Tindakan Bantuan Hidup Dasar. Jurnal Kesehatan Perintis (Perintis's Health Journal), 5(2), pp 139 - 144.

Sharek, P.J., Parast, L.M., Leong, K., Coombs, J., Earnest, K., Sullivan, J., Frankel, L.R. \& Roth, S.J. (2007). Effect of a rapid response team on hospital-wide mortality and code rates outside the ICU in a Children's Hospital. JAMA, 298(19), pp 2267-2274.

Simmons, B. (2010). Clinical reasoning: Concept analysis. Journal of Advanced Nursing, 66, 1151-1158.

Waldie, J., Tee, S. \& Day, T. (2016). Reducing avoidable deaths from failure to rescue: a discussion paper. British Journal of Nursing (Mark Allen Publishing), 25(16), pp 895-900. 